\title{
An Analysis of Higher-Order Thinking: Examining a Secondary Physics I Web-Enhanced Instructional Design
}

\author{
Lisa M. Coolidge Manley Ph.D. \\ Central Connecticut State University
}

\begin{abstract}
This paper discusses a small-scale study assessing the extent to which the instructional design of a web-enhanced educational learning environment using a discussion board as a Computer Mediated Communication (CMC) tool facilitated higher-order thinking processes. The study was carried out in an online Physics I module with 38 male and female high school students. Group discussion posts and students' final analyses were coded and analyzed using the Garrison, Anderson, and Archer (2001) Community of Inquiry (Col) model. Two raters coded more than 300 discussion messages using cognitive presence categories and indicators to determine the level of higher-order thinking processes. Each message was given a number relating to the model's categories: $1=$ triggering, $2=$ exploration, 3 =integration, $4=$ resolution, and $5=$ social. Each category helped determine the level of social presence. Results suggested that $8 \%$ of participant groups' postings moved to higher levels of thinking processes using authentic learning activities, a CMC discussion board tool, and guidance from a teacher. However, $32 \%$ could not move beyond exploration. Over $43 \%$ of student postings were categorized as social, an increase over previous studies in higher education. Data also indicated that $50 \%$ of all participants scored in the higher-order thinking levels on their final analyses rather than in the discussion thread. Based on these results, this paper concludes that well-designed online learning modules-offering learners authentic learning activities, CMC collaborative tools, prompting questions, and teacher presence-must be accompanied by precise, structured directives for secondary learners to achieve higher levels of critical thinking within collaborative discussion groups.
\end{abstract}

The potential for asynchronous online discussions to encourage reflection and meaningful information processing outside the classroom has been noted by Bai (2009), Garrison, Anderson, and Archer (2001), Kanuka and Garrison (2004), McLoughlin and Mynard (2009), and Meyer (2003). Some of these same researchers, however, have encountered unsatisfactory results when utilizing discussion board tools within learning management systems (LMS) such as WebCT and Blackboard (Bai, 2009; McLoughlin \& Mynard, 2009). The literature suggests that Computer Mediated Communication (CMC) tools, such as discussion boards, must be accompanied by online instructional strategies, such as authentic learning and problem solving, to help learners achieve higher-order levels of thinking (Bai, 2009; Kanuka, 2005; Rockinson-Szapkiw, 2009), but the majority of studies 
on this subject focus on higher education, rather than $\mathrm{K}-12$ education conducted online (Cavanaugh, Gillan, Kromrey, Hess, \& Blomeyer, 2004; Huett, Moller, Foshey, \& Coleman, 2008; Rice, 2006). This lack of study in K-12 online education represents a significant gap in the literature, given the substantial size and consistent growth of online offerings within K-12 education. The National Center for Education Statistics estimated that more than a third of K-12 school districts in the United States "had students taking technologysupported distance education courses" as long ago as the 2004-05 school year, and that more than a million K-12 students enrolled in online classes during the 2007-08 school year (Means et al., 2009, p. 1).

Hein and Irvine (1998) indicated that students must become active participants in the learning process in order to achieve meaningful learning, which they define as "deep understanding and not simply rote memorization of facts, as well as long-term retention of concepts" (p. 1). Online discussion groups, specifically asynchronous discussions, allow learners to become active in the learning process by communicating, collaborating, and reflecting with the instructor and other students. Andresen (2009) noted several benefits of asynchronous online discussions, including extended time for students to reflect and reply, the absence of interruptions from the teacher or other students while responding, and the creation of a written document that can be studied and assessed.

This study used the Garrison et al. (2001) Community of Inquiry (Col) model to measure the existence of higher-order thinking within the discussion threads of the online student groups. The Col model has been successfully used to identify higher-order thinking in previous related research (Bai, 2009; Kanuka \& Garrison, 2004; McLoughlin \& Mynard, 2009; Meyer, 2003). The intent of this study was to first determine whether higher-order thinking processes took place collaboratively in an educational context reliant on CMC discussion board tools and specific instructional strategies. A second intent was to extend to a secondary educational context the validity of the Col model in assessing higherorder thinking processes within a collaborative CMC-mediated learning environment.

\section{Literature Review}

For years, educators have noted students' desire for hands-on, technology-rich learning environments (Baird \& Fisher, 2006; Campbell \& Oblinger, 2007; Huett et al., 2008; Johnson, Levine, Smith, \& Stone, 2010). The literature reports that many members of "(Gen M)" (Wallis, 2006) can multitask using multiple forms of technology-such as computers, tablets, video and audio devices and cell phones-allowing them to become active learners (Baird \& Fisher, 2006; Campbell \& Oblinger, 2007; Estrad, 2003; Prensky, 2001). This shift in learners' expectations has led to corresponding changes in instructional design, as educators search constantly for appropriate tools and instructional strategies to engage learners.

This rosy view of online technology is not held universally, however. Some learners find it challenging to complete tasks online, from interpreting and comprehending information to cognitive problem solving once data is gathered (Huett et al., 2008; Wallis, 2006). 
Designing effective online learning environments requires that we address these failures, particularly within learning environments outside the usual research context of higher education. The first step is to explore and assess younger learners' abilities to utilize the $\mathrm{CMC}$ tools and learner-centered instructional strategies common in online learning environments.

Research suggests that constructivist and social constructivist techniques can help to establish a sense of community among online participants (Rockinson-Szapkiw, 2009; Rovai 2002; Shea, Li \& Pickett, 2006). CMC discussion threads, tied in with diverse instructional strategies, can foster this sense of community and contribute to the existence of higher-order thinking processes (Bai, 2009; McLoughlin \& Mynard, 2009; Meyer, 2004).

The literature also supports the use of Col as an effective tool to measure the impacts of social, teacher, and cognitive presence, as well as students' need for continual validation (Bai, 2009; Garrison et al., 2000; Kanuka \& Garrison, 2004; McLoughlin \& Mynard, 2009; Meyer, 2004). Garrison et al. define the three aspects of Col presence as follows:

Social Presence is the ability of participants in the Col to project their personal characteristics into the community. Teacher presence is the presence of a subject matter expert who can design an effective educational experience and share in the facilitation. Cognitive presence, which is considered the most critical, is where the participants in any particular configuration of a Col are able to construct meaning through sustained communication (Garrison et al., 2000, p. 89).

This study's use of Col to assess the degree of cognitive presence, if any, adds to the existing body of research, and extends the validity of the Col model in measuring higherorder thinking processes using the $\mathrm{CMC}$ tool discussion board.

\section{Benefits, Challenges and Concerns}

Online education allows educators to provide "authentic connections to a learning environment beyond the school boundaries," a goal outlined more than a decade ago by Cavanaugh (2001, p. 85), who noted the potential of such an approach to match the increasing focus on learning standards situated in the real world. Online learners can join others, forming communities of learners that work together to complete tasks or solve problems. Social media technologies further this sense of community, which is essential to the building of social presence and the acquisition of cognitive presence. Baird and Fisher (2005), in their study on social media-enhanced instructional strategies for "neomillennial" students, concluded that "[s]ocial networking media engages the user in the content and allows them to be included as an active participant as they construct a learning landscape rooted in social interaction, knowledge exchange, and optimum cognitive development with their peers" (p. 24).

The age of online learners is a significant consideration when designing and implementing 
online learning environments. While some students benefit from asynchronous online technologies - which offer flexibility in choosing when, where and how to learn (Huett et al., 2008)-younger learners may not excel in such open-ended environments. Krebs (2004) found that younger students tend to perform better when offered a more structured learning environment with more instructor guidance, clearer expectations and set deadlines. Concerns of autonomy, metacognition, motivation, and self-regulating skills are just a few areas that need to be addressed in online learning environments (Cavanaugh et al., 2004; Huett et al., 2008; Ronsisvalle \& Watkins, 2005). Thus, online environments designed for younger learners must feature teacher presence in order to establish social and cognitive presence.

Also of concern are the digital differences between young learners and the educational system (Clark, Logan, Luckin, Mee, \& Oliver, 2009). Social media technologies have not been widely accepted in the formal K-12 setting for various reasons, including a lack of evidence regarding educational benefits, the failure of instructors and administrators to understand how they work, and the insufficient research regarding instructional strategies and tool use for younger learners (Clark et al. 2009). Educators must take the time to explore the benefits of utilizing various $\mathrm{CMC}$ tools, and identify instructional strategies capable of supporting social, cognitive, and teacher presence in online education for younger learning audiences.

\section{Community of Inquiry Model}

The Col framework was designed to measure the teaching and learning processes within an asynchronous text-based environment (Garrison et al., 2000, 2001; RockinsonSzapkiw, 2009). Within this framework, "learning is seen as part of a collaborative process of constructing meaningful knowledge" (McLoughlin \& Mynard, 2009, p.149). Literature tends to support the idea that the use of CMC tools and development of social presence is necessary, but only as part of the process for successful student collaboration and learning outcomes (Hughes, Ventura, \& Dando, 2007; Tu \& Mclsaac, 2002). Cognitive presence is a vital component to a learner's critical thinking process. Without the ability for higher-order thinking, lifetime learning may not take place (Garrison et al. 2000; Garrison \& Cleveland-Innes, 2005; McLoughlin \& Mynard, 2009).

The Col model consists of three key

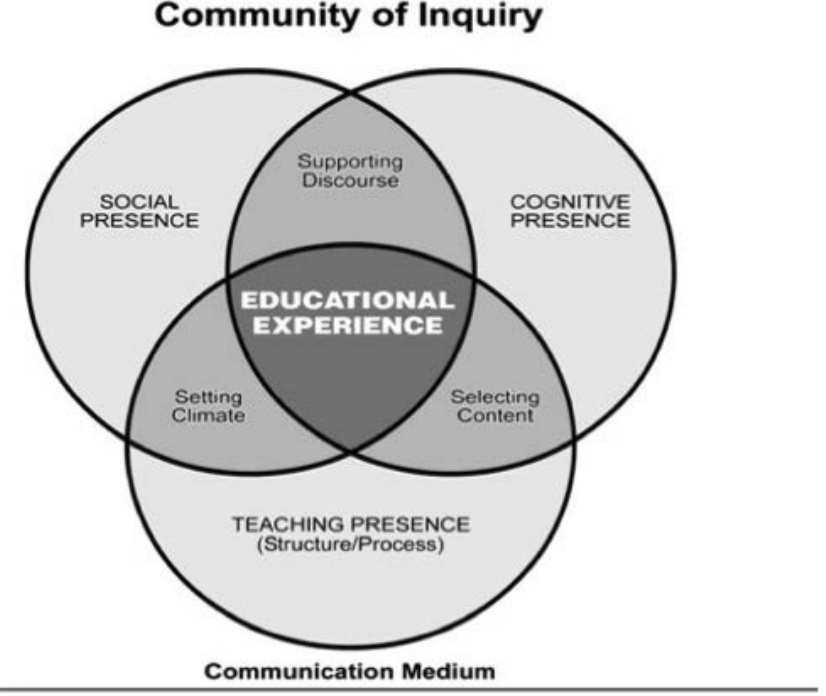

Figure 1. Community of Inquiry framework makes up elements of an educational experience. Adapted from "Critical inquiry in a text-based environment: Computer conferencing in higher education." by D. R. Garrison, T. Anderson and W. Archer, 2000, The Internet and Higher Education, 2(2-3), 87-105. Reprinted with permission. 
elements: cognitive presence, social presence, and teacher presence. These elements are considered essential to the educational community and to the interaction of teachers and students, both online and face-to-face. Each element has been given its own coding templates, which have been formed by indicators created from key words, phrases, or synonyms found in computer conferencing transcripts. The indicators have been categorized into each of the three presence elements (see Table 1). From these indicators, researchers are able to determine if cognitive, social, or teacher presence is evident within a computer text-based environment (Bai, 2009; Kanuka \& Garrison, 2004; Ke, 2010; McLoughlin \& Mynard, 2009; Meyer, 2003). Although the three components are interdependent, few previous studies have examined their coexistence (Garrison, 2007; Garrison, Cleveland, \& Fung, 2004; Shea \& Bidjerano, 2009).

Table 1

Community of Inquiry Coding Template

\begin{tabular}{|l|l|l|}
\hline Elements & Categories & Indicators (examples only) \\
\hline Cognitive Presence & Triggering Event & Sense of puzzlement \\
& Exploration & Information exchange \\
& Integration & Connecting ideas \\
& Resolution & Apply new ideas \\
\hline Social Presence & Emotional Expression & Emotion \\
& Open Communication & Risk-free expression \\
& Group Cohesion & Encouraging collaboration \\
\hline Teaching Presence & Instructional Management & Defining and initiating discus- \\
& Building Understanding & Sharing personal meaning \\
& Direct Instruction & Focusing discussion \\
\hline
\end{tabular}

Community of Inquiry framework coding template adapted from Garrison, D. R., Anderson, T., \& Archer, W. (2000). Critical inquiry in a text-based environment: Computer conferencing in higher education. The Internet and Higher Education, 2(2-3). Reprinted with permission.

\section{Assessing Higher-Order Thinking}

Cognitive presence is considered the most important element for the critical thinking process to occur. Garrison et al. (2001) states, "Cognitive presence reflects higher-order knowledge acquisition and application" (p. 11). The ability to assess the processes of critical thinking within a community of inquiry allows a more heuristic means of evaluating learning and the ability to reach deeper meaning within one's cognition. The idea of cognitive presence is rooted in Dewey's construction of practical inquiry, which searches for critical thinking as its outcome (Garrison et al., 2000) and is considered the most challenging component of the Col framework to "study and develop in online courses" (Garrison \& Arbaugh, 2007, p. 161).

Various studies have sought the existence of higher-order thinking demonstrated in online discussion groups using CMC tools (Bai, 2009; Kanuka \& Garrison, 2004; 
McLoughlin \& Mynard, 2009; Meyer, 2003). Using the Col framework to assess levels of critical thinking, research has determined that higher-order thinking does take place. However, in a majority of the studies, resolution, which is the Col model's highest level of thinking process, is hard to obtain unless the objective of the discussion was to solve a problem or find a solution (Bai, 2009; Garrison, 2007; Garrison \& Arbaugh, 2007; Kanuka \& Garrison, 2004; Meyer, 2003, 2004). McLoughlin and Mynard's (2009) small-scale case study utilized the Col framework to assess online discussion forums in determining the existence of higher-order thinking. The structure of the course was both face-to-face and online. Using Col as a means to measure cognitive presence, the results were similar to other related studies (Bai, 2009; Meyer, 2003), indicating that higher-order thinking was evident. However, concerns arose regarding the level of thinking reached in the studies since many of the participants could not move beyond the integration phase to the resolution phase. The McLoughlin and Mynard (2009) study resulted in 52.5\%

Table 2

Comparison of Three Studies Using Community of Inquiry Model

\begin{tabular}{|c|c|c|c|c|c|c|c|}
\hline Authors & \begin{tabular}{|l|} 
Title \\
\end{tabular} & \begin{tabular}{|l} 
Sample \\
Size \\
\end{tabular} & \begin{tabular}{|l|} 
Type of \\
Study \\
\end{tabular} & Model & \multicolumn{3}{|l|}{ Findings } \\
\hline $\begin{array}{l}\text { Meyer } \\
(2003)\end{array}$ & \begin{tabular}{|l|} 
Face-to- \\
face versus \\
threaded \\
discussions: \\
The role of \\
time and \\
higher-order \\
thinking \\
\end{tabular} & $\begin{array}{l}{ }^{*} N=751 \\
\text { postings }\end{array}$ & \begin{tabular}{|l|} 
Qualitative \\
Content \\
Analysis
\end{tabular} & $\begin{array}{l}\text { Community } \\
\text { of Inquiry } \\
\text { Garrison, } \\
\text { Anderson, } \\
\text { \& Archer } \\
\text { (2000) } \\
\text { Coding } \\
\text { Template } \\
\end{array}$ & \multicolumn{3}{|c|}{$\begin{array}{l}\text { Trigger }=8 \% \\
\text { Exploration }=51 \% \\
\text { Integration }=22 \% \\
\text { Resolution }=7 \% \\
\text { Social }=3 \% \\
1 \text { rater (Researcher) }\end{array}$} \\
\hline Bai (2009) & \begin{tabular}{|l} 
Facilitating \\
student's \\
critical \\
thinking \\
in online \\
discussions: \\
An instructors \\
experience \\
\end{tabular} & $\begin{array}{l}A-N=38 \\
\text { messages } \\
B-N=68 \\
\text { messages }\end{array}$ & \begin{tabular}{|l} 
Qualitative \\
Content \\
Analysis
\end{tabular} & $\begin{array}{l}\text { Community } \\
\text { of Inquiry } \\
\text { Garrison, } \\
\text { Anderson, } \\
\text { \& Archer } \\
\text { (2000) } \\
\text { Coding } \\
\text { Template } \\
\end{array}$ & $\begin{array}{l}\text { Trigger }= \\
\text { Explore = } \\
\text { Integration = } \\
\text { Resolution = } \\
\text { No Social } \\
1 \text { rater }\end{array}$ & \begin{tabular}{|l}
$A$ \\
$8 \%$ \\
$87 \%$ \\
$5 \%$ \\
$0 \%$ \\
\end{tabular} & \begin{tabular}{|l}
$B$ \\
$22 \%$ \\
$54 \%$ \\
$24 \%$ \\
$0 \%$
\end{tabular} \\
\hline $\begin{array}{l}\text { McLoughlin } \\
\text { \& Mynard } \\
\text { (2009) }\end{array}$ & $\begin{array}{l}\text { An analysis } \\
\text { of higher } \\
\text { order thinking } \\
\text { in online } \\
\text { discussions }\end{array}$ & $\begin{array}{l}\text { N=102 } \\
\text { postings } \\
\text { per } \\
\text { Instructor } \\
\star 204 \\
\text { posting } \\
\text { total }\end{array}$ & \begin{tabular}{|l|} 
Qualitative \\
Content \\
Analysis
\end{tabular} & $\begin{array}{l}\text { Community } \\
\text { of Inquiry } \\
\text { Garrison, } \\
\text { Anderson, } \\
\text { \& Archer } \\
\text { (2000) } \\
\text { Coding } \\
\text { Template }\end{array}$ & \multicolumn{3}{|c|}{$\begin{array}{l}\text { Trigger }=3 \% \\
\text { Exploration }=53 \% \\
\text { Integration }=34 \% \\
\text { Resolution }=5 \% \\
\text { Social }=4 \% \\
2 \text { raters (Both instructors } / \\
\text { researchers) }\end{array}$} \\
\hline
\end{tabular}

Note: All three studies were held in courses that meet face-to-face and offer online components (i.e. discussion forums). 
exploration, 34.3\% integration, and only $5.4 \%$ resolution. The Bai (2009) study had $87 \%$ of group $A$ and $54 \%$ of group B in exploration, $2 \%$ of group $A$ and $16 \%$ of group B in integration, and $0 \%$ in both group $A$ and $B$ in resolution. Meyer (2003) found $51 \%$ as exploration, $22 \%$ as integration and $7 \%$ as resolution (see Table 2).

The concern over the lack of movement toward the resolution phase has been discussed in various studies (Garrison, 2007; Garrison \& Arbaugh, 2007; Garrison et. al, 2001; Kanuka \& Anderson, 1998; Kanuka, Rourke, \& LaFlamme, 2007; Meyer, 2003, 2004). McLoughlin and Mynard (2009) concluded "that the nature of the course, type of task, and wording of initial prompt have an effect on type of higher-ordering thinking processes that will emerge in an online discussion" (p. 156). Bai (2009) inferred that the lack of resolution results was due to the fact that the study did not offer students engaging questions, but that it asked them instead to talk about what they already knew. It is therefore important to ask thought-provoking questions that will engage the learner in higher levels of thinking processes such as problem-solving (Garrison, 2007). Meyer (2003) suggested that the low level of participants' thinking skills could have been the result of such factors as the complexity of the issues raised, an information or skill gap, or "a missed opportunity on the part of faculty who could have pressed for a resolution to questions being raised by the discussion" (p. 63).

\section{The Study}

\section{Research Questions}

1. How and to what extent will the instructional design of a web-enhanced educational environment using a discussion board as a CMC tool facilitate higher-order thinking processes?

2. How and to what extent will the use of the cognitive presence indicators from Garrison, Anderson, and Archer's (2001) Community of Inquiry model prove to be a viable means of assessment for measuring higher-order thinking processes as expressed through $\mathrm{CMC}$ discourse?

\section{Methodology}

A qualitative approach was chosen due to the nature of the study, which examines high school level discourse for the existence of higher-order thinking processes. Qualitative research, according to Creswell (2008), "relies on the views of participants; asks broad, general questions; collects data consisting largely of word (or text) from participants; describes and analyzes these words for themes; and conducts the inquiry in a subjective, biased manner" (p. 46). This qualitative study analyzed student online discourse using the indicators from the Col model's cognitive presence, which has been accepted as a viable form of measurement for sustainable and meaningful discourse in the higher education context among researchers (Bai, 2009; Garrison et al., 2001; Kanuka \& Garrison, 2004; McLoughlin \& Mynard, 2009). 
The method chosen for the research was a case study, which is typically chosen for a particular entity (Lichtman, 2010). The case study was a replication of preexisting studies, which has utilized the Col model to analyze the existence of higher-order thinking processes of learners within online discussion forums in a higher educational setting (Bai, 2009; McLoughlin \& Mynard, 2009; Meyer, 2003). The purpose of the study was to examine the use of discussion boards, along with appropriate instructional strategies, to facilitate higher-order thinking processes in high school Physics I students. Secondly, the study helped to validate the use of Garrison et al.'s (2001) Col model as a means of assessing the existence of higher-order thinking processes in high school students.

The study was focused around a single case sample of 40 secondary educational participants across three Physics I courses. Of the 40 possible participants, 38 participated in the study after parental consent was signed. The demographics broke down into $47 \%$ young women $(n=18)$ and $53 \%$ young men $(n=20)$, ranging in age from $16-17$. The group participants were drawn from three Physics I classes by the physics instructor so each group would have a learner from each Physics I class. Two of the classes were Honors $(\mathrm{H})$ level, and the third was College Preparation (CP) level. The study involved 14 collaborative groups in total. The first 12 groups broke down into smaller groups of $2(\mathrm{H})$ and 1 (CP); however, the (CP) participants in groups 9 and 10 were missing in action and did not contribute to the dialogue or analysis. Groups 13 and 14 consisted of only $2(\mathrm{H})$ participants since the (CP) Physics class had fewer participants.

\section{Design of Online Learning Module}

The instructional design and theoretical framework that formed the basis of the Physics I web-enhanced learning module focused around three models: Garrison, Anderson and Archer's (2001) Col model; Jonassen's (1999), Constructivist Learning Environment (CLE); and Anderson and Krathwohl's (2001) Bloom's Revised Taxonomy (see Table 3). The three theoretical frameworks work cohesively in the instructional design process to build a learning module, offering a community of inquiry that will support higher-order thinking and a more meaningful learning experience.

Community of Inquiry model implementation. The Col framework aided in creating an environment rich in interaction, collaboration, and connection to community needed to establish social, teacher, and, the most critical, cognitive presence. The Col framework is a well-structured model that has been utilized in both online and blended learning environments in higher education (Bai, 2009; Garrison \& Cleveland-Innes, 2005; Kanuka, 2005; Kanuka \& Garrison, 2004; Meyer, 2003). The model offers guidelines on how to create effective learning communities and puts emphasis on both collaboration and critical thinking, which grounds cognitive presence within the Col framework (Garrison et al., 2001).

Constructivist Learning Environment model implementation. Jonassen's (1999) Constructivist Learning Environment (CLE) model was designed for students to be active learners in the learning process and to have the ability to communicate and collaborate with a community of learners. Jonassen's design of CLE infers that the learner constructs 
Table 2

Building Components

\begin{tabular}{|c|c|c|c|}
\hline Module Building Components: & \begin{tabular}{|l|} 
Community \\
of Inquiry \\
(Col) \\
\end{tabular} & \begin{tabular}{|l|} 
Constructivist \\
Learning \\
Environment (CLE) \\
\end{tabular} & Bloom's Taxonomy \\
\hline $\begin{array}{l}\text { Introductory question asked to get } \\
\text { learners to engage in reflection } \\
\text { and dialogue with other learners } \\
\text { across classes and with instructor } \\
\text { using collaborative tools. }\end{array}$ & Social & Social/Contextual & $\begin{array}{l}\text { Remembering, } \\
\text { Understanding, Applying }\end{array}$ \\
\hline $\begin{array}{l}\text { Give learner an opportunity to } \\
\text { explore surroundings within a } \\
\text { community of inquiry }\end{array}$ & $\begin{array}{l}\text { Social, } \\
\text { Teacher \& } \\
\text { Cognitive } \\
\end{array}$ & Social/Contextual & Understanding, Applying \\
\hline $\begin{array}{l}\text { Link to movie player (Quicktime or } \\
\text { Windows Movie Player) }\end{array}$ & \begin{tabular}{|l|} 
Social, \\
Teacher \& \\
Cognitive \\
\end{tabular} & Social/Contextual & Applying \\
\hline $\begin{array}{l}\text { Link to Adobe Reader to read PDF } \\
\text { files }\end{array}$ & \begin{tabular}{|l} 
Social, \\
Teacher \& \\
Cognitive
\end{tabular} & Social/Contextual & Applying \\
\hline $\begin{array}{l}\text { Learning Resources: Written } \\
\text { material: rubrics, expectations, } \\
\text { articles (Word or PDF files) } \\
\end{array}$ & $\begin{array}{l}\text { Cognitive, } \\
\text { Teacher }\end{array}$ & \begin{tabular}{|l} 
Related Cases \\
\& Information \\
Resources \\
\end{tabular} & $\begin{array}{l}\text { Remembering, } \\
\text { Understanding, Applying }\end{array}$ \\
\hline Examples & $\begin{array}{l}\text { Cognitive, } \\
\text { Teacher }\end{array}$ & $\begin{array}{l}\text { Related Cases } \\
\text { \& Information } \\
\text { Resources } \\
\end{array}$ & $\begin{array}{l}\text { Remembering, } \\
\text { Understanding, Applying }\end{array}$ \\
\hline $\begin{array}{l}\text { Video: clips of movies to use for } \\
\text { assignment }\end{array}$ & Cognitive & Cognitive Tools & \begin{tabular}{|l} 
Remembering, \\
Understanding \\
\end{tabular} \\
\hline Internet searching & Cognitive & Cognitive Tools & $\begin{array}{l}\text { Applying, Understanding, } \\
\text { Remembering }\end{array}$ \\
\hline Concept mapping & Cognitive & \begin{tabular}{|l|} 
Cognitive/ \\
Collaborative Tools \\
\end{tabular} & \begin{tabular}{|l} 
Remembering, \\
Understanding, Analyzing \\
\end{tabular} \\
\hline \begin{tabular}{|l|} 
Discussion Board \\
Reflection/Responses
\end{tabular} & \begin{tabular}{|l|} 
Social, \\
Teacher \& \\
Cognitive \\
\end{tabular} & Collaborative Tools & $\begin{array}{l}\text { Understanding, Analyzing, } \\
\text { Evaluating }\end{array}$ \\
\hline $\begin{array}{l}\text { Upload document access: Final } \\
\text { written report }\end{array}$ & Cognitive & \begin{tabular}{|l} 
Cognitive Tools \\
\end{tabular} & Evaluating \\
\hline
\end{tabular}

Building components sources: Jonassen, D. H. (1999). Designing constructivist learning environments. In C. M. Reigeluth (Ed.), Instructional-Design Theories and Models, (Vol. II, pp. 215-239). Mahwah, NJ: Erlbaum Associates; Anderson, L. W., \& Krathwohl, D. R. (2001). A taxonomy for learning, teaching and assessing: $A$ revision of Bloom's Taxonomy of educational objectives. Complete edition. New York, NY: Longman.; Garrison, D. R., Anderson, T., \& Archer, W. (2000). Critical inquiry in a text-based environment: Computer conferencing in higher education. The Internet and Higher Education, 2(2-3). 
his or her own knowledge both socially and individually based on the interpretations of his or her experiences in the world. Using this form of learning environment, the Physics I learning module offered students a problem to solve collaboratively using related cases and information resources that provided the learner with background knowledge. The information resources supported the following: general understanding and possible solutions, cognitive tools as a means of interpretation and manipulation of the problem, conversation/collaboration tools to form communities of learners that will help construct meaning, and social/contextual support for the implementation of the CLE.

Bloom's Revised Taxonomy model implementation. The online Physics I learning module also tied into the revised Bloom's Taxonomy model. The original Bloom's Taxonomy was developed by Benjamin Bloom in 1956 as a means of defining intellectual skills or cognition. Using a hierarchical approach this model moved the cognition process from simplest to more complex, using the following classification areas: Knowledge, Comprehension, Application, Analysis, Synthesis, and Evaluation. However, to meet the needs of 21st century learners, Anderson, a former student of Bloom, and Krathwohl (2001) revised Bloom's Taxonomy by renaming and reversing some of the hierarchical

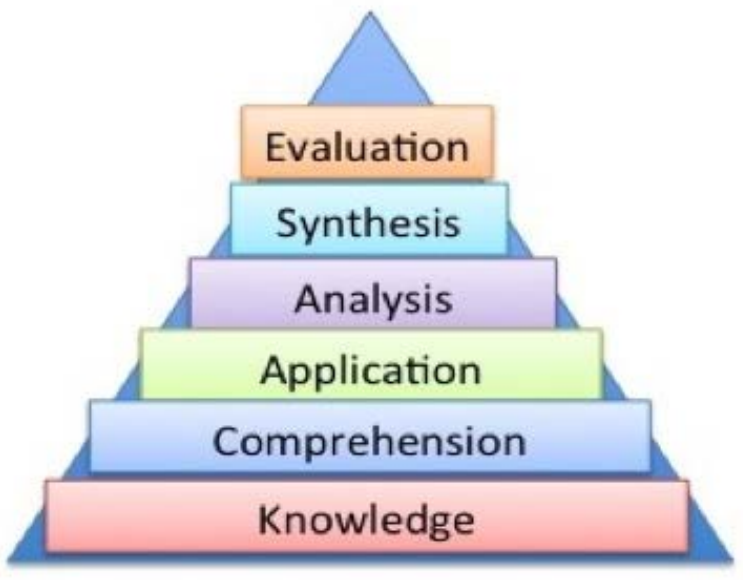

Bloom's Taxonomy

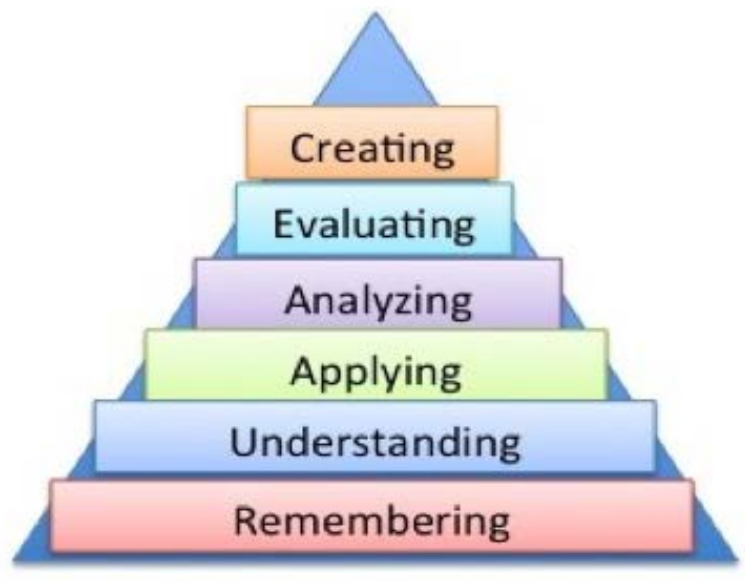

$21^{\text {st }}$ Century Bloom's Taxonomy

Figure 2. Original Bloom's Taxonomy (1956) and 21st Century Bloom's Taxonomy, adapted from Anderson \& Krathwohl (2001).

design (see Figure 2).

In addition to the revised taxonomy, authentic learning activities were offered to support the learner's autonomy (Anderson, Poelhuber \& McKerlich, 2010; McLoughlin \& Lee, 2008; Reeves, Herrington \& Oliver 2002; Rovai, 2007). Collaborative asynchronous online discussion threads offered the learners time to reflect and respond to the problem, as well as to the ongoing discourse within their group (McLoughlin \& Mynard, 2009; Meyer, 2003). Guidelines and expectations were given to the participants as with the McLoughlin and Mynard (2009) study. The online discussion task-requesting learners to use higherorder thinking processes-was unfamiliar, and participants were graded on this task. 
Teacher presence was also available throughout the module on physics in various film genres. As the research has indicated, learner-instructor interaction is critical in an online learning environment in order to facilitate critical thinking processes (Garrison et al., 2001; Rovai, 2007; Schrire, 2006; Wu \& Hiltz, 2004).

\section{Inter-rater Reliability}

The study utilized two outside raters, for the pursuit of unbiased results, as well as a research assistant to eliminate student names for the purpose of anonymity. The two raters analyzed each student's postings separately after being acquainted with the Col model. Using the critical thinking categories of Garrison et al. (2001), each rater determined the appropriate category, indicator, and socio-cognitive processes represented in each individual posting. Similar to the pre-existing study by McLoughlin and Mynard (2009), this research used the Garrison et al. (2001) method of coding when more than one category is evident in the message. "If it is unclear from the content what is the most appropriate category it will be coded down, and if there is clear evidence of multiple categories it will be coded up" (p. 152). For instance if the message showed positive themes of triggering and exploration, then the message was coded exploration; if the theme of the message was unclear, then it was coded triggering. The results were then analyzed to determine the degree (if any) of higher order thinking within the discussion board discourse. As stated previously, the acquired data added to the validation of the Garrison et al. (2001) Col model as a viable framework for instructional designers to measure cognitive presence in an online learning environment using $\mathrm{CMC}$ tools.

Two methods of inter-rater reliability were utilized to measure the agreement between the two coders. Both methods were used in the replicated study to determine the level of agreement. The first measurement was Holsti's coefficient of reliability (1969). As with the McLoughlin and Mynard (2009) study, this form of inter-rater reliability measurement is based on percent agreement as determined by comparing the number of agreements between the coders to the total number of coding decisions. The coefficiency of reliability for each category uses Holsti's formula $U=(01-\mathrm{O} 2) /(\mathrm{O} 1+\mathrm{O} 2) . \mathrm{U}=$ disagreement was

Table 5

Inter-rater Reliability Agreement Scores Using Holsti's Coefficient of Reliability

\begin{tabular}{|r|l|}
\hline Category & Holsti's Coefficient of Reliability \\
\hline Triggering & .882 \\
\hline Exploration & .981 \\
\hline Integration & .889 \\
\hline Resolution & 1.0 \\
\hline Social & .881 \\
\hline
\end{tabular}

used then to determine the agreement levels (see Table 5). Holsti's coefficient formula of measurement shows a high percentage of agreement between raters for each category. The second method utilized was Cohen's kappa $(k)$, which measured the reliability after 
taking chance agreements between the two coders into consideration. Using the formula $\mathrm{K}=\mathrm{p}$ (observed) - $\mathrm{p}$ (expected by chance) / 1 - $\mathrm{p}$ (expected by chance), the overall kappa score of $(N=311)$ student postings for two raters was .694. Using the kappa formula for inter-rater reliability does not prove strong cohesive agreement with the two raters. However, as Capozzoli, McSweeney, and Subgam (as cited in McLoughlin \& Mynard, 2009) state:

[V]alues greater than 0.75 or so may be taken to represent excellent agreement beyond chance, values below 0.40 or so may be taken to represent poor agreement beyond chance, and values between 0.40 and 0.75 may be taken to represent fair to good agreement beyond chance. ( $p$. 6)

\section{Findings}

Participants were asked to participate in a research study involving a module on physics in various film genres, which utilized the discussion board tool found in the eSchool Builder LMS. Participants were engaged in a collaborative discussion thread that explored, selected, formulated, and resolved various physics problems. Data accrued over two weeks. The group discussion board messages, as well as the attached group problem analyses, were taken from the LMS discussion board after the study was completed.

The data collected from the discussion board consisted of each group message treated as a whole, and the final physics analysis from each group participant. Participants' discourse and final analyses were collected and sent to a research assistant to remove personally identifiable

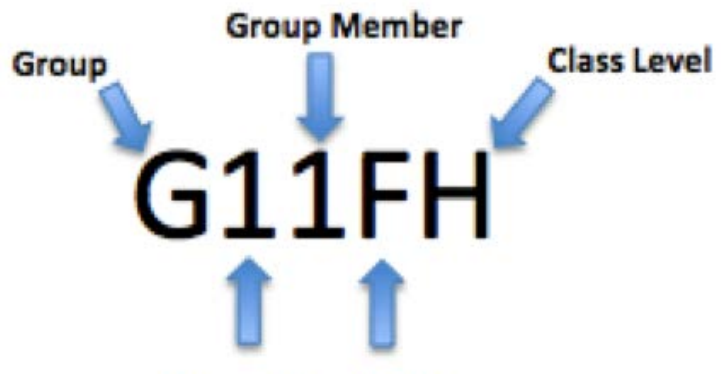

Group \# Gender

Figure 3. Classification code given to each participant. information and replace this with general codes that identified the group, gender, and class level of each participant (see Figure 3). This was undertaken to protect the minor participants.

The data collected in this case study were analyzed using a content analysis approach comparable to that of McLoughlin and Mynard (2009). The data were treated as categorical in order to answer the following question: "To what extent will the instructional design of a web-enhanced educational environment using the discussion board as a CMC tool facilitate higher-order thinking processes?" The following sections discuss the results of the data collected regarding the research question.

\section{Facilitation of Higher-Order Thinking Processes}

Student participants contributed a total of $(\mathrm{N}=311)$ postings throughout the two-week 
movie physics study. With two raters coding the group discourse, a total of 622 message scores were tallied. Adding both raters' scores and calculating average percentages determined that $33 \%$ of the discourses featured triggering and exploration, and only $8 \%$ scored in the Col model's higher level of critical thinking process of integration and resolution. Over $43 \%$ of the two raters' coding scores were deemed social, and $16 \%$ of the overall scores could not be coded to any Col or social category (see Figure 4). It is also important to point out that the differences in rater coding scores in this study was more significant than those in previous studies. The number of messages they determined

\section{Raters COI Student Post Summary}

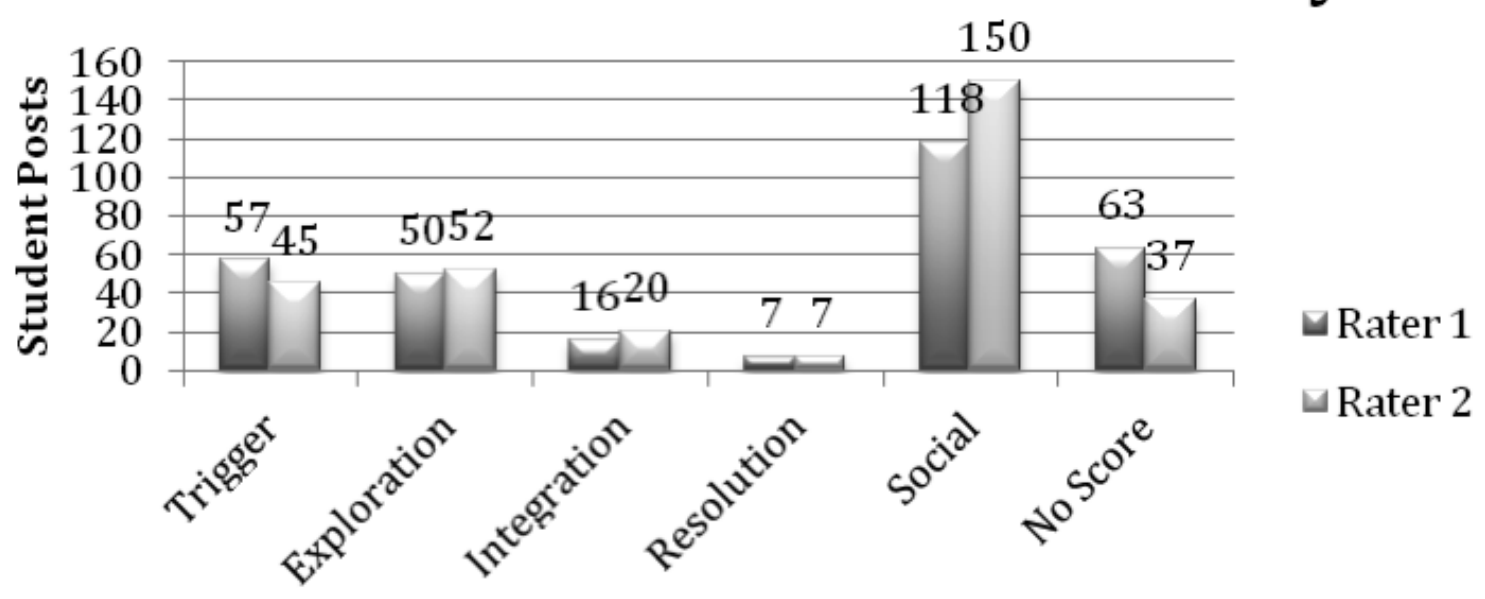

CoI Categories

Figure 4. Graph of 2 raters' final coding scores from Col model.

to be social interaction also outweighed scores from previous studies held in higher education (Bai, 2009; McLoughlin \& Mynard, 2009; Meyer 2003). These differences could not be analyzed, as no interviews were scheduled with the raters.

The data indicates that for the larger population of group participants, the online learning module and the use of the CMC discussion board tool did not facilitate a higher level of thinking. An average of $92 \%(\mathrm{~N}=286)$ of the participants' messages remained in the social, triggering, and exploration phases of thinking. Examples of social interaction, triggering, and exploration from participants follow.

Social:

G21MH: Hey who else is in group 2?

G121MH: Hi group 12 it's XXXX I was wondering who else was in this group with me? The movies I was thinking of doing were the first wild coyote, Hancock or the Spiderman clip were he stops a moving train. Let me know what you think.

Triggering: 
G41FH: A few possible things we might be able to analyze are how far he falls the first time, how high the entire cliff is, and with how much force he lands? Also we could probably do something with launched projectiles at the point where he hits the bottom and the rock lands on top of him. Any more suggestions?

G101FH: Ok that sounds good, i think im going to do the part where they have to make the turn and determine the force needed to make it. How much should we say the weight of the cars are and what their speed is?

Exploration:

G52FCP: Question. What is the final velocity of scrat while falling?

The perito moreno glacier has an averge height of $74 \mathrm{~m}$.

$\mathrm{t}=$ square root of $2 \times 74 / 9.8$

$\mathrm{t}=3.8 \mathrm{~s}$

Vfinal=Vi-9.8×3.8

Vfinal $=9.8 \times 3.8$

Vfinal $=37.24 \mathrm{~m} / \mathrm{s}$

G82FH: I'm planning to do the thing on a hill with the man in the wheelbarrow rolling down the hill. We can figure the average weight of a man 6'1" (the height of Tom Hanks) is $167 \mathrm{lbs}$ which converts to $76 \mathrm{~kg}$.

http://www.healthdiscovery.net/links/calculators/ideal_bw_men.htm

http://www.alibaba.com/productgs/299704498/wheelbarrowWB8029_ with_WB6409_frame.html

The total mass of the man in the wheelbarrow would therefore be $92 \mathrm{~kg}$.

The coefficient of $\mu$ of a tire on the grass is 0.35

http://physics.info/friction/

All participants were given detailed online instructions, links to YouTube videos about physics, online rubrics on both the two-week study and discussion board usage, and instructor guidance throughout the project. The instructional design of the physics web-enhanced discussion board study was developed from both prior face-to-face interaction and Internet research on applied physics. Participants were given movie physics examples, which provided an opportunity to use problem-solving skills online 
within the discussion board, prior to the study.

Analysis of ratings showed that $5.7 \%$ of group messages made it to the integration phase, showing collaboration by building off other members' ideas. The following dialogue from group 14 demonstrates their ability to move toward a higher level of thinking through the use of the discussion board. Each participant built off the other to formulate ideas and work towards a cohesive agreement as to what and how the problems could be solved.

G141MH: I'll take the first 1:05 of the clip and cover the distance the train covers before a force is applied (delta $x$, time, vf and vi, that kind of thing), and if you want, you can do like the stopping distance from when Spidey starts to stop the train to when he finishes, friction between the tracks and him, or like you said, the negative acceleration of the train after he begins to slow it down.

G142MH: Okay, sounds good! For my analysis I'm going to look at the negative acceleration in the train and the tension in the webs. So far research wise, I've found that

1.once the webs are in place, the train travels approximately 150 meters in 48 seconds.

2.2. The train is initially traveling 36 meters per second

3.3. The train's mass is about $4.9 \times 10^{\wedge} 5 \mathrm{~kg}$ (based on six cars each being $\left.6.5 \times 10^{\wedge} 4 \mathrm{~kg}\right)$

4.4. The coefficient of kinetic friction for hard steel on steel is .42

G141MH: Nice! In my segment, I found that before Spiderman starts to slow down the train, it travels for 48s. I used the two speeds shown on the speedometer to convert the initial speed from $60 \mathrm{mph}$ to $2.7 \mathrm{~m} / \mathrm{s}$ and the same for $80 \mathrm{mph}$ to $3.6 \mathrm{~m} / \mathrm{s}$, however I think these velocities are too low so I'm not sure if I converted them correctly.

G142MH: using the acceleration $\left(\mathrm{vf}^{\wedge} 2-\mathrm{Vi} \wedge 2\right) /(2$ deltax $)=\mathrm{a}$ and the research, it appears that the train would have to accelerate at $-21.3 \mathrm{~m} / \mathrm{s} / \mathrm{s}$ in order to make the stop in time before the break in the track, which is stretching it to say the least.

G141MH: I believe you moved a decimal somewhere, for 80 mphi got 36 $\mathrm{m} / \mathrm{s}$ which sounds a little more reasonable

G142MH: Yeah I will agree that I think I did. Thank you for helping me find my correction. Now I can revise my horizontal kinematics equations to rework my results, which they will make much more sense now. 
The final requirement for each group in the module on physics in various film genres was to complete two or three individual physics analyses, depending on the number of participants in the groups. The goal was to have the solutions stated in the discourse and then transcribed to a group document that would be attached within each discussion board group discourse. As the data indicates, only $2.3 \%$ were able to achieve the resolution phase within the discussion thread, which is the Col model's highest level of thinking process. The following is a continued example of Group 14 as they resolved their chosen physics equations.

G142MH: And following this, for a second tension analysis, the tension equals the mass and acceleration of the train minus friction $T=m a-(F n x$ .42) Using this equation I found that the tension in each string (he shoots eight on each side) would be 1,000,000 newtons) Even though spider silk is extremely strong, I doubt it could withstand such forces. Unfortunately I couldn't find the actual tensile strength of spider silk.

G141MH: Attached is my final analysis. I chose to do the segment of the video clip chosen for this group from 0:00, to 1:05, which is examining the horizontal kinematics of the train before any forces (Spiderman) begin to act on it. The time, $t$, was founded by timing how long it took from the time the train began to run wild, to when Spiderman began to stop the train, which resulted in 48s. Also, the clip showed the beginning speed $(60 \mathrm{mph}$, or $27 \mathrm{~m} / \mathrm{s})$, and the ending speed $(80 \mathrm{mph}$, or $36 \mathrm{~m} / \mathrm{s})$, which were also used. They resulted in the finding of acceleration first using the equation $\mathrm{Vf}=\mathrm{Vi}+\mathrm{at} . .$.

Some participants utilized the discussion board as a means to socialize and bounce ideas off of other group members, but waited until the individual component of the study moved into the resolution phase, making it an individual experience rather than a collaborative event. A strong foundation of social presence is important in order to achieve critical discourse (Garrison \& Cleveland-Innes 2005), but it must also be structured with tutorial and instructor guidance to keep the discourse on task, especially for a young audience (Rice, 2006). Participants in this study had difficulties maintaining an ongoing conversation within the groups that progressed into higher-level thinking processes.

One possible explanation for the lack of higher-order thinking processes could be the participants' multitasking technology habits. Research has indicated that the quality of one's ability to express and reach a level of meaningful knowledge can deteriorate when they overtask themselves (Wallis, 2006). Teens are known to chat or email with friends, watch videos or play games and search the Internet typically at the same time (Baird \& Fisher, 2006; Campbell \& Oblinger, 2007; Estrad, 2003; Prensky, 2001; Wallis, 2006). Studies have determined that social presence is a building block for discourse so participants can move on to more meaningful discourse levels. Kreijns, Kirschner, and Jochems (2003) stated that social relationships contribute to group cohesion, common understanding, and orientation towards cooperation and the desire to remain in their 
group (p. 343). More research in the area of social presence within high school-level online discourse could provide further insight on collaborative meaningful learning.

\section{Results and Discussion}

The data support previous findings that online discussion threads have the potential to inspire higher-order thinking processes (Bai, 2009; McLoughlin \& Mynard, 2009; Meyer, 2003). Data is summarized and analyzed below.

\section{Research Question 1}

Research question one dealt with the extent to which the instructional design of a webenhanced educational environment using the discussion board $\mathrm{CMC}$ tool facilitates higher-order thinking processes. Raters' evidence showed that $5.7 \%(\mathrm{~N}=18)$ participants' postings were able to reach the integration phase and $2.3 \%(\mathrm{~N}=7)$ participants' postings were able to achieve resolution phase using the movie physics collaborative $\mathrm{CMC}$ online discussion board (see Table 6). Both integration and resolution are part of the higher-

Table 6

Average Participants and Percentage of Two Raters

\begin{tabular}{|r|r|l|}
\hline Col Event Categories & Average \# Raw Participants' Postings & Average Percentage Postings \\
\hline Triggering & 51 & $16.4 \%$ \\
\hline Exploration & 51 & $16.4 \%$ \\
\hline Integration & 18 & $5.7 \%$ \\
\hline Resolution & 7 & $2.3 \%$ \\
\hline Social/0ther & 184 & $59.2 \%$ \\
\hline Total & 311 & $100 \%$ \\
\hline
\end{tabular}

order thinking processes in the Col model. Compared to the replicated studies in higher education (Bai, 2009; McLoughlin \& Mynard, 2009; Meyer, 2003), the average postings reaching the resolution phase are similar, considering that the participants in this study were younger learners with minimal to no online learning experience. The differences run in the percentage of integration as shown in following sections.

The three comparable studies, Bia (2009) Group B. 24\%, McLoughlin and Mynard (2009) $34 \%$, and Meyer (2003) $22 \%$, show that a higher percentage of higher educational learners were able to reach the integration phase when offered authentic learning activities and collaborative CMC discussion board tools. However, only $6 \%$ of participants in the current study reached the integration phase. Other results showed that $16.4 \%(\mathrm{~N}=51)$ of participants' posts to discussion boards were able to achieve triggering, and the same number and percentage reached the exploration phase. The high number of messages with a social element (43\%) was expected, especially given the age group of the participants, and the need for students to get to know their team members. Although 
Table 7

Demographics, Final Outcomes, and Col Scores

\begin{tabular}{|c|c|c|c|c|c|}
\hline \multirow[b]{2}{*}{ Group \# } & \multirow[b]{2}{*}{ Group Member - \# Posts } & \multirow[b]{2}{*}{ Final Analysis Scores } & \multirow[b]{2}{*}{ Categories } & \multicolumn{2}{|c|}{ Col Scores } \\
\hline & & & & R1 & $\mathbf{R 2}$ \\
\hline Group 1 & $\begin{array}{l}\text { G11FH - 8 } \\
\text { G12FH - 4 } \\
\text { G13MCP - } 6 \\
2 F / 1 M-2 H / 1 C P\end{array}$ & $\begin{array}{l}3 \\
3 \\
3\end{array}$ & \begin{tabular}{|l|} 
Triggering \\
Exploration \\
Integration \\
Resolution \\
Social \\
Other \\
Total
\end{tabular} & $\begin{array}{l}7 \\
4 \\
1 \\
0 \\
5 \\
1 \\
\mathbf{1 8}\end{array}$ & $\begin{array}{l}7 \\
4 \\
1 \\
0 \\
3 \\
3 \\
\mathbf{1 8}\end{array}$ \\
\hline Group 2 & $\begin{array}{l}\text { G21MH }-13 \\
\text { G22MH }-8 \\
\text { G23FCP }-6 \\
1 F / 2 M-2 H / 1 C P\end{array}$ & $\begin{array}{l}4 \\
3 \\
3\end{array}$ & $\begin{array}{l}\text { Triggering } \\
\text { Exploration } \\
\text { Integration } \\
\text { Resolution } \\
\text { Social } \\
\text { Other } \\
\text { Total }\end{array}$ & $\begin{array}{l}5 \\
2 \\
1 \\
0 \\
18 \\
1 \\
27\end{array}$ & $\begin{array}{l}2 \\
1 \\
1 \\
0 \\
21 \\
2 \\
27\end{array}$ \\
\hline Group 3 & $\begin{array}{l}{ }^{\star} \mathrm{G} 31 \mathrm{MH}-14 \\
\mathrm{G} 32 \mathrm{FH}-9 \\
{ }^{\star} \mathrm{G} 33 \mathrm{MCP}-9 \\
1 \mathrm{~F} / 2 \mathrm{M}-2 \mathrm{H} / 1 \mathrm{CP}\end{array}$ & $\begin{array}{l}4 \\
4 \\
4\end{array}$ & \begin{tabular}{|l|} 
Triggering \\
Exploration \\
Integration \\
Resolution \\
Social \\
Other \\
Total \\
\end{tabular} & $\begin{array}{l}5 \\
7 \\
3 \\
3 \\
10 \\
4 \\
32 \\
\end{array}$ & $\begin{array}{l}5 \\
6 \\
3 \\
3 \\
10 \\
5 \\
32 \\
\end{array}$ \\
\hline Group 4 & $\begin{array}{l}\text { G41FH }-10 \\
\text { G42MH }-5 \\
\text { G43MCP }-9 \\
1 F / 2 M-2 H / 1 C P\end{array}$ & $\begin{array}{l}4 \\
3 \\
3\end{array}$ & \begin{tabular}{|l|} 
Triggering \\
Exploration \\
Integration \\
Resolution \\
Social \\
Other \\
Total
\end{tabular} & $\begin{array}{l}8 \\
3 \\
0 \\
0 \\
11 \\
2 \\
24\end{array}$ & $\begin{array}{l}9 \\
3 \\
0 \\
0 \\
10 \\
2 \\
24\end{array}$ \\
\hline Group 5 & $\begin{array}{l}\text { G51FH }-3 \\
\text { G52FCP }-2 \\
\text { G53FH }-2 \\
3 F-2 H / 1 C P\end{array}$ & $\begin{array}{l}2 \\
2 \\
2\end{array}$ & \begin{tabular}{|l|} 
Triggering \\
Exploration \\
Integration \\
Resolution \\
Social \\
Other \\
Total
\end{tabular} & $\begin{array}{l}2 \\
3 \\
0 \\
0 \\
1 \\
1 \\
7\end{array}$ & $\begin{array}{l}3 \\
3 \\
0 \\
0 \\
0 \\
1 \\
7\end{array}$ \\
\hline Group 6 & $\begin{array}{l}\text { G61MH }-12 \\
\text { G62FH }-9 \\
\text { G63MCP }-2 \\
1 F / 2 M-2 H / 1 C P\end{array}$ & $\begin{array}{l}3 \\
3 \\
\text { No score }\end{array}$ & $\begin{array}{l}\text { Triggering } \\
\text { Exploration } \\
\text { Integration } \\
\text { Resolution } \\
\text { Social } \\
\text { Other } \\
\text { Total }\end{array}$ & $\begin{array}{l}6 \\
2 \\
-- \\
-- \\
15 \\
-- \\
23 \\
\end{array}$ & $\begin{array}{l}6 \\
2 \\
-- \\
-- \\
15 \\
-- \\
23\end{array}$ \\
\hline Group 7 & $\begin{array}{l}\text { G71MH - } 11 \\
\text { G72MH - } 14 \\
\text { G73MCP - } 6 \\
3 M-2 H / 1 C P\end{array}$ & $\begin{array}{l}4 \\
4 \\
3\end{array}$ & \begin{tabular}{|l|} 
Triggering \\
Exploration \\
Integration \\
Resolution \\
Social \\
Other \\
Total
\end{tabular} & \begin{tabular}{|l|}
5 \\
7 \\
2 \\
0 \\
6 \\
11 \\
31
\end{tabular} & $\begin{array}{l}3 \\
6 \\
5 \\
0 \\
13 \\
4 \\
31\end{array}$ \\
\hline
\end{tabular}


Table 7 (continued)

\begin{tabular}{|c|c|c|c|c|c|}
\hline \multirow[b]{2}{*}{ Group \# } & \multirow[b]{2}{*}{ Group Member - \# Posts } & \multirow[b]{2}{*}{ Final Analysis Scores } & \multirow[b]{2}{*}{ Categories } & \multicolumn{2}{|c|}{ Col Scores } \\
\hline & & & & R1 & R2 \\
\hline Group 8 & $\begin{array}{l}\text { G81FH }-10 \\
\text { G82FH }-7 \\
\text { G83MCP }-4 \\
2 F-1 M-2 H / 1 C P\end{array}$ & $\begin{array}{l}3 \\
3 \\
3\end{array}$ & \begin{tabular}{|l|} 
Triggering \\
Exploration \\
Integration \\
Resolution \\
Social \\
Other \\
Total
\end{tabular} & $\begin{array}{l}3 \\
2 \\
0 \\
0 \\
11 \\
5 \\
21\end{array}$ & $\begin{array}{l}1 \\
2 \\
0 \\
0 \\
13 \\
5 \\
21 \\
21\end{array}$ \\
\hline Group 9 & $\begin{array}{l}{ }^{*} \mathrm{G} 91 \mathrm{FH}-19 \\
{ }^{\star} \mathrm{G} 92 \mathrm{MH}-8 \\
\text { Missing Participant } \\
1 \mathrm{~F} / 1 \mathrm{M}-2 \mathrm{H}\end{array}$ & $\begin{array}{l}4 \\
4 \\
\text { No score }\end{array}$ & \begin{tabular}{|l|} 
Triggering \\
Exploration \\
Integration \\
Resolution \\
Social \\
Other \\
Total \\
\end{tabular} & \begin{tabular}{|l|}
4 \\
2 \\
0 \\
2 \\
15 \\
4 \\
27 \\
\end{tabular} & \begin{tabular}{|l|}
1 \\
3 \\
0 \\
2 \\
17 \\
4 \\
27 \\
\end{tabular} \\
\hline Group 10 & $\begin{array}{l}\text { G101FH - } 6 \\
\text { G102MH }-6 \\
\text { Missing Participant } \\
\text { 1F/1M - 2H }\end{array}$ & $\begin{array}{l}3 \\
4 \\
\text { No score }\end{array}$ & \begin{tabular}{|l} 
Triggering \\
Exploration \\
Integration \\
Resolution \\
Social \\
Other \\
Total
\end{tabular} & $\begin{array}{l}3 \\
2 \\
0 \\
0 \\
5 \\
2 \\
12\end{array}$ & $\begin{array}{l}1 \\
2 \\
0 \\
0 \\
8 \\
1 \\
12\end{array}$ \\
\hline Group 11 & $\begin{array}{l}\text { G111MCP }-7 \\
\text { G112FH }-4 \\
\text { G113FH }-7 \\
2 F / 1 M-2 H / 1 C P\end{array}$ & $\begin{array}{l}3 \\
4 \\
3\end{array}$ & \begin{tabular}{|l} 
Triggering \\
Exploration \\
Integration \\
Resolution \\
Social \\
Other \\
Total
\end{tabular} & \begin{tabular}{|l|}
2 \\
1 \\
0 \\
0 \\
14 \\
1 \\
18
\end{tabular} & $\begin{array}{l}2 \\
0 \\
0 \\
0 \\
15 \\
1 \\
\mathbf{1 8}\end{array}$ \\
\hline Group 12 & $\begin{array}{l}\text { G121MH }-7 \\
\text { G122FCP }-5 \\
\text { G123FH }-5 \\
2 F / 1 M-2 H / 1 C P\end{array}$ & $\begin{array}{l}4 \\
3 \\
3\end{array}$ & \begin{tabular}{|l|} 
Triggering \\
Exploration \\
Integration \\
Resolution \\
Social \\
Other \\
Total
\end{tabular} & \begin{tabular}{|l}
2 \\
6 \\
1 \\
0 \\
5 \\
3 \\
17
\end{tabular} & $\begin{array}{l}2 \\
6 \\
0 \\
0 \\
7 \\
2 \\
17 \\
\end{array}$ \\
\hline Group 13 & $\begin{array}{l}\mathrm{G} 131 \mathrm{MH}-20 \\
\mathrm{G} 132 \mathrm{FH}-14 \\
1 \mathrm{~F} / 1 \mathrm{M}-2 \mathrm{H}\end{array}$ & $\begin{array}{l}4 \\
4\end{array}$ & \begin{tabular}{|l|} 
Triggering \\
Exploration \\
Integration \\
Resolution \\
Social \\
Other \\
Total \\
\end{tabular} & \begin{tabular}{|l|}
5 \\
7 \\
3 \\
0 \\
1 \\
18 \\
34 \\
\end{tabular} & \begin{tabular}{|l|}
3 \\
12 \\
4 \\
0 \\
11 \\
4 \\
34 \\
\end{tabular} \\
\hline Group 14 & $\begin{array}{l}{ }^{*} \mathrm{G} 141 \mathrm{MH}-12 \\
{ }^{*} \mathrm{G} 142 \mathrm{MH}-8 \\
2 \mathrm{M}-2 \mathrm{H}\end{array}$ & $\begin{array}{l}3 \\
3\end{array}$ & \begin{tabular}{|l|} 
Triggering \\
Exploration \\
Integration \\
Resolution \\
Social \\
Other \\
Total
\end{tabular} & \begin{tabular}{|l}
0 \\
2 \\
5 \\
2 \\
1 \\
10 \\
20
\end{tabular} & $\begin{array}{l}0 \\
2 \\
6 \\
2 \\
7 \\
3 \\
20\end{array}$ \\
\hline
\end{tabular}


several students' discussion board postings did not reach higher-order levels of thinking, 34 out of 38 participants were able to score in the higher-order thinking levels in the hardcopy group final analyses (see Table 7).

The study found that a well-designed online learning module offering learners authentic learning activities, CMC tools to collaborate, prompting questions, and teacher presence must be accompanied with precise structured directives (see Appendices) for secondary learners in order to facilitate higher levels of critical thinking within collaborative discussion groups. The results add to the research of younger online learners' abilities in achieving higher-order thinking process that will guide instructional designers in creating effective online learning environments for younger audiences.

\section{Research Question 2}

This section discusses the findings of the second research question: How, and to what extent, are cognitive presence indicators from the Col model (Garrison et al., 2001) a viable means of assessing higher-order thinking processes as expressed through CMC discourse? The Col cognitive presence categories and indicators as shown in Table 4 allowed the raters to categorically code each message for the appropriate level or phase of the higher-order thinking process obtained by group participants.

Table 4

Col Cognitive Presence Assessment Rubric

\begin{tabular}{|c|c|}
\hline 1 - Triggering & $\begin{array}{l}\text { 1. Presents background information that culminates in a question (Recognition of a } \\
\text { problem) } \\
\text { 2. Asks questions to address puzzlement } \\
\text { 3. Takes discussion in new direction }\end{array}$ \\
\hline 2 - Exploration & $\begin{array}{l}\text { 1. Presents many different ideas/themes, some could be unsubstantiated contradic- } \\
\text { tions of previous ideas (Divergence) } \\
\text { 2. Exchanges information including personal narratives/descriptions/facts (not used as } \\
\text { evidence to support a conclusion) } \\
\text { 3. Adds to established points but does not systematically defend/justify/develop addi- } \\
\text { tion (Brainstorming) } \\
\text { 4. Being explicitly characterized as exploration }\end{array}$ \\
\hline 3 - Integration & $\begin{array}{l}\text { 1. Reference to previous message followed by substantiated agreement, e.g., "I agree } \\
\text { because...." (Convergence) } \\
\text { 2. Builds on or adds to other's ideas (Convergence) } \\
\text { 3. Provides justified, developed, defensible, yet tentative hypotheses } \\
\text { 4. Connecting ideas or synthesizing ideas by integrating information from various } \\
\text { sources - textbooks, articles, personal experience. } \\
\text { 5. Creates solution }\end{array}$ \\
\hline 4 - Resolution & $\begin{array}{l}\text { 1. Various applications to real world } \\
\text { 2. Testing solutions } \\
\text { 3. Defending solutions }\end{array}$ \\
\hline 5 - Social & $\begin{array}{ll}\text { 1. } & \text { Emotions } \\
\text { 2. } & \text { Risk-free expression } \\
\text { 3. } & \text { Encouraging collaboration } \\
\end{array}$ \\
\hline
\end{tabular}


The raters-both veteran high school English teachers-were selected for their ability to assess critical thinking in a narrative context. Raters were able to categorically code each message into the appropriate level or Col phase of the higher-order thinking process (see Table 4). Raters were given the same tools and instruction as the participants regarding the Col cognitive indicators, as well as the expectations and rubrics. The social category used in both McLoughlin and Mynard (2009) and Meyer (2003) studies was also added. Raters determined $41 \%$ of the messages made it to the four Col cognitive presence categories. Raters also scored an average of $(\mathrm{N}=134)$ social messages of the $(\mathrm{N}=311)$ posting totals, and an average $(\mathrm{N}=50)$ went to the no-score category totaling $(\mathrm{N}=184)$. That makes up $59 \%$ of the total messages never making it to the cognitive presence categories.

The data supports the effective use of the Col cognitive presence categories and indicators. The use of the Col model was effective in assessing higher-order thinking processes, and also acted as a guide for participants to follow when collaborating in online discourse problem-solving (see Appendix A).

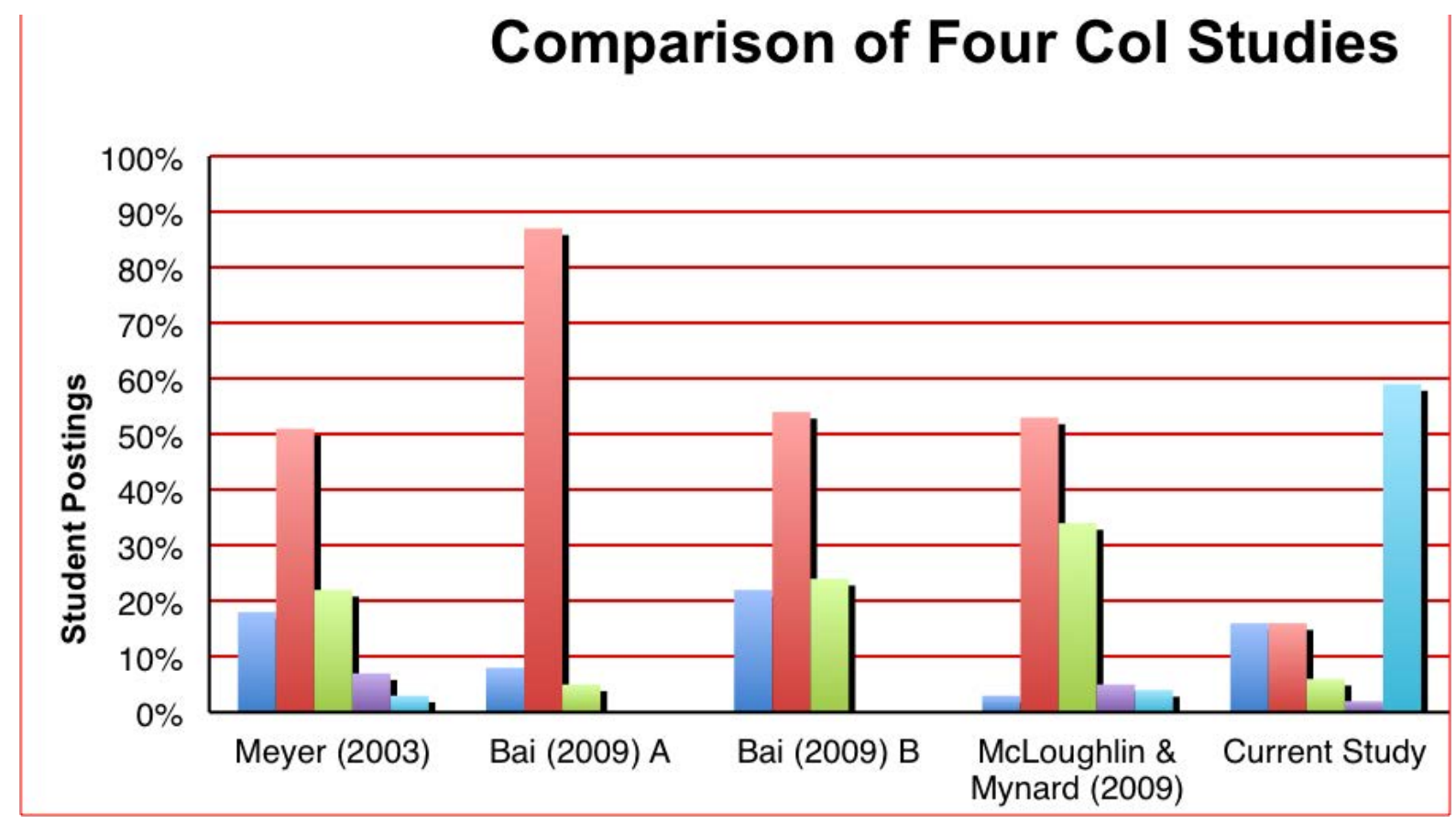

Figure 5. Comparison of Four Col Studies.

The categorical comparisons with the three other studies using the Col cognitive presence indicator (Bai, 2009; McLoughlin \& Mynard, 2009; Meyer, 2003) show that this research is second in total number of posting overall. The categorical percent of each of the cognitive presence indicators other than resolution indicates quite a difference from previous studies, especially in the exploration and integration phases (see Figure 5).

The three higher education studies rated the majority of their student postings in the 
exploration phase (Bai, 2009; McLoughlin \& Mynard, 2009; Meyer, 2003). Exploration phase scores in the current secondary school study were quite low in comparison, at just $16 \%$. In fact, raters determined a majority of the secondary student postings to be considered either social or undeterminable for any category. The reason is unclear as to the high percentage of social and non-scored student posting messages, since a followup interview of raters was not part of the study's methodology.

The use of Col cognitive presence indicators to measure levels of higher-order thinking is important to the instructional design of online learning environments. Determining categorically when deeper learning occurs enables instructional designers to incorporate those factors which move discourse beyond social interaction and lower-level thinking. Past studies have determined that prompts and teacher presence guide learners to improve their levels of thinking (Bai, 2009; McLoughlin \& Mynard, 2009). The current study demonstrates that Col indicators can be used to determine secondary students' abilities to reach higher-order levels of thinking in a given environment. Equally significant, data also indicated that younger learners may need more structure and teacher presence to move the discourse beyond the social phase.

\section{Future Research}

The study focused on a small group of secondary Physics I participants and the influence that the inquiry model's cognitive presence guidelines had on an individual's critical thinking abilities combined with the use of the CMC discussion board tool and the integration of discussion threads and collaborative, problem solving instructional strategies. Future studies should further explore the area of cognitive presence in regard to the use of the CMC discussion board tool and the integration of instructional strategies in other subject areas in secondary education. Using more than one subject area can broaden the study's findings in order to help validate the Col model's cognitive presence indicators as a means to assess higher-order thinking processes with secondary level learners. Also, the addition of participant interviews or surveys could add to the research on the secondary learners' critical thinking abilities, comfort levels of content and context, technology and collaborative skills, and overall satisfaction. An added interview with raters could also clear up any inter-rater reliability issues that could occur.

\section{Conclusion}

The instructional design of an online learning environment is critical to an adolescent learner. Studies have indicated that the medium alone does not create effective online learning (Clark, 1994; Rice, 2006), but it must also be integrated with various instructional strategies to allow the learner to achieve deeper understanding (Bai, 2009; McLoughlin \& Mynard, 2009; Meyer, 2003). This study examined the use of the specific CMC tool, the discussion board, in association with the instructional strategies of discussion threads and collaborative problem solving and the overall effects on the acquisition of higherorder thinking processes with secondary Physics I learners. The results showed that younger learners were able to achieve higher critical thinking abilities in the online learning 
environment. The results also showed that a lesser percentage of younger learners could achieve higher levels than adult learners, but without surveys or interviews the study could not determine the reason for the lower level of higher-order thinking processes and the higher level of social and non-scored student posting messages. The results of the study will benefit instructional designers when developing and choosing the right $\mathrm{CMC}$ tools and instructional strategies for online problem-solving discourse-especially for secondary learners. Studies have shown that younger learners need well-designed instruction, teacher presence, and the opportunities to be active, collaborative learners in order to become successful online learners (Rice, 2006).

The data in this study could not clearly indicate whether the use of the Col model's cognitive presence indicators, when used as guidelines similar to the Bia (2009) study, were effective in assisting participants to move through the critical thinking levels. One recommendation would be to incorporate surveys or interviews with participants to determine the guidelines' effectiveness. Results of the study, however, did determine the success of using the Col model as a means in assessing higher-order thinking processes of the secondary Physics I learners. Although more of the resolution level was left to the uploaded individual documents of the learners, three participant groups were able to collaborate and achieve the Col resolution phase in the online discussion thread. Further studies with secondary level learners are needed to determine which CMC tools and instructional strategies work to effectively improve K-12 learners in their online learning critical thinking abilities. 


\section{References}

Anderson, L. W., \& Krathwohl, D. R. (2001). A taxonomy for learning, teaching and assessing: A revision of Bloom's Taxonomy of educational objectives. Complete edition. New York, NY: Longman.

Anderson, T., Poelhuber, B., \& McKerlich, R. (2010). Self-paced learners' meet social software: An exploration of learners' attitudes, expectations and experience. Journal of Distance Education Administration, 13(3). Retrieved from http://www. westga.edu/ distance/ojdla/Fall133/anderson_poellhuber_mcKerlich133.html

Andresen, M. A. (2009). Asynchronous discussion forums: Success factors, outcome, assessments, and limitations. Educational Technology \& Society, 12(1), 249-257. Retrieved from http://www.ifets.info/journals/12_1/19.pdf

Bai, H. (2009). Facilitating students' critical thinking in online discussion: An instructor's experience. Journal of Interactive Online Learning, 8(2), 156-164. Retrieved from http://www.ncolr.org/jiol/issues/

Baird, D. E., \& Fisher, M. (2006). Neomillennial user experience design strategies: Utilizing social networking media to support "always on" learning styles. Journal of Educational Technology Systems, 34(1), 5-32. doi:10.2190/6WMW-47L0-M81Q$12 \mathrm{G} 1$

Campbell, J. P., \& Oblinger, D. G. (2007). Top ten teaching and learning issues. Educause Quarterly, 30(3), 15-22. Retrieved from http://net.educause.edu/ir/library/pdf/ eqm0732.pdf

Cavanaugh C. S. (2001). The effectiveness of interactive distance education technologies in K-12 learning: A meta-analysis. International Journal of Educational Telecommunications, 7(1). 73-88. Retrieved from http://www.editlib.org/p/8461

Cavanaugh, C., Gillan, K., Kromrey, J., Hess, M., \& Blomeyer, R. (2004). The effects of distance education on K-12 student outcomes: A meta-analysis. Naperville, IL: Learning Point Associates. Retrieved from www.ncrel.org/tech/distance/index. html

Clark, R. E. (1994). Media will never influence learning. Education Technology, Research, and Development, 42(2), 21-29. doi:10.1007/BF02299088

Clark, W., Logan, K., Luckin, R., Mee, A., \& Oliver, M. (2009) Beyond Web 2.0: Mapping the technology landscapes of young learners. Journal of Computer Assisted Learning, 25, 56 -69.

Creswell, J. W. (2008). Educational research: Planning, conducting, and evaluating quantitative and qualitative research. Upper Saddle River, NJ: Pearson. 
Driscoll, M. P. (2005). Psychology of learning for instruction. (3 ${ }^{\text {rd }}$ ed.) Boston: Pearson

Estrad, O. (2003) Electracy as empowerment: Student activities in learning environment using technology. Nordic Journal of Youth Research, 11(1), 11-28. doi:10.1177/1103308803011001073

Garrison, D. R. (2007). Online community of inquiry review: Social, cognitive, and teaching presence issues. Journal of Asynchronous Learning Networks, 11(1), 6172. Retrieved from http://sloanconsortium.org/sites/default/files/v11n1_8garrison. pdf

Garrison, D. R., Anderson, T., \& Archer, W. (2000). Critical inquiry in a text-based environment: Computer conferencing in higher education. The Internet and Higher Education, 2(2-3), 87-105. doi:10.1016/S1096-7516(00)00016-6

Garrison, D. R., Anderson, T., \& Archer, W. (2001). Critical thinking, cognitive presence, and computer conferencing in distance education. American Journal of Distance Education, 15(1), 7-23. doi:10.1080/08923640109527071

Garrison, D. R., \& Arbaugh, J. B. (2007). Researching the Community of Inquiry framework: Review, issues and future directions. The Internet and Higher Education, 10(3), 157-172. doi:10.1016/j.ineduc.2007.04.001

Garrison D. R., \& Cleveland-Innes, M., (2005). Facilitating cognitive presence in online learning: Interaction is not enough. The American Journal of Distance Education, 19(3), 133-148. doi:10.1207/s15389286ajde1903_2

Garrison D. R., \& Cleveland-Innes, M., \& Fung, T. (2004). Student role adjustment in online communities of inquiry: Model and instrument validation. Journal of Asynchronous Learning Network, 8(2), 61-74. Retrieved from http://sloanconsortium.org/system/ files/v8n2_garrison.pdf

Hein, T. L. \& Irvine, S. E. (1998). Assessment of student understanding using on-line discussion groups. $28^{\text {th }}$ Annual Frontiers in Education Conference. Moving from 'Teacher-Centered' to 'Learner-Centered' Education. Conference Proceedings, 130-135. doi:10.1109/FIE.1998.736819

Holsti, O. (1969). Content analysis for the social sciences and humanities. Don Mills, ON: Addison-Wesley.

Huett, J., Moller, L., Foshay, W.F., \& Coleman, C. (2008). The evolution of distance education: Implications for instructional design on the potential of the web. TechTrends, 52(5), 63-67. Retrieved from http://search.proquest.com.library. capella.edu/docview/223118296?accountid=27965 
Hughes, M., Ventura, S., \& Dando, M. (2007). Assessing social presence in online discussion groups: A replication study. Innovations in Education and Teaching International, 44(1), 17-29. doi:10.1080/14703290601090366

Johnson, L., Levine, A., Smith, R. and Stone, S. (2010). The 2010 Horizon Report, The New Media Consortium. Austin, TX. Available at: http://wp.nmc.org/horizon2010/

Jonassen, D. H. (1999). Designing constructivist learning environments. In C. M. Reigeluth (Ed.), Instructional-Design Theories and Models, Vol. II (pp. 215-239). Mahwah, NJ: Erlbaum Associates.

Kanuka, H. (2005). An exploration into facilitating higher levels of learning in a text-based internet learning environment using diverse instructional strategies. Journal of Computer-Mediated Communication, 10(3), 00. doi:10.1111/j.1083-6101.2005. tb00256.x

Kanuka, H., \& Garrison, D.R. (2004). Cognitive presence in online learning. Journal of Computing in Higher Education, 15(2), 30-48. doi:10.1007/BF02940928

Kanuka, H., Rourke, L., \& LaFlamme, E. (2007). The influence of instructional methods on the quality of online discussion. British Journal of Educational Technology, 38(2), 260-271. doi:10.111/j.1467-8535.2006.00620.x

Ke, F. (2010). Examining online teaching, cognitive, and social presence for adult students. Computers \& Education, 55, 808-820. doi:10.1016/j.compedu.2010.03.013

Krebs, T. J. (2004). Implementing an online web design course module at a suburban high school: A phenomenological case study. (Doctoral dissertation). Retrieved from ProQuest Dissertations and Theses. (305042889)

Kreijns, K., Kirschner, P. A., Jochems, W. (2003). Identifying the pitfalls of social interaction in computer-supported collaborative learning environments: A review of the research. Computers in Human Behavior, 19(3), 335-353. doi:10.1016/S07475632(02)00057-2

Lichtman, M. (2010). Qualitative research in education: A user's guide. Thousand Oaks, CA: Sage.

McLoughlin, C., \& Lee, M. (2008). Mapping the digital terrain: New media and social software as catalysts for pedagogical change. In Hello! Where are you in the landscape of educational technology? Proceedings ascilite Melbourne 2008. 641652. Retrieved from http://www.ascilite.org.au/conferences/melbourne08/procs/ index.htm

McLoughlin, D., \& Mynard J. (2009). An analysis of higher order thinking in online discussions. Innovations in Education and Teaching International, 46(2), 147-160. doi:10.1080/14703290902843778 
Meyer, K. A. (2003). Face-to-face versus threaded discussions: The role of time and higher-order thinking. Journal of Asynchronous Learning Networks, 7(3), 55-65. Retrieved from http://www.sloanconsortium.org/publications/jaln_main.

Meyer, K.A. (2004). Evaluating online discussions: Four different frames of analysis. Journal of Asynchronous Learning Networks, 5(2), 101-114. Retrieved from: http:// www.sloan-c.org/publications/jaln/index.asp.

Prensky, M. (2001). Digital natives, digital immigrants Part 1. On the Horizon, 9(5), 1-6. doi:10.1108/10748120110424816

Prensky, M. (2001). Digital Natives, Digital Immigrants Part 2: Do They Really Think Differently? On the Horizon, 9(6), 1-6. doi:10.1108/10748120110424843

Reeves, T.C., Herrington, J., \& Oliver, R. (2002). Authentic activities and online learning. In A. Goody, J. Herrington, \& M. Northcote (Eds.), Quality conversations: Research and Development in Higher Education, 25 (pp. 562-567). Jamison, ACT: HERDSA.

Rice, K. (2006). A comprehensive look at distance education in the K-12 context. Journal of Research on Technology in Education, 38(4), 425-447. Retrieved from http:// www.editlib.org/p/27245

Rockinson-Szapkiw, A. J. (2009). The impact of asynchronous and synchronous instruction and discussion on cognitive presence, social presence, teaching presence, and learning. (Doctoral Dissertation)., Retrieved from http://gradworks. umi.com/3370135

Ronsisvalle, T., \& Watkins, R. (2005). Student success in online K-12 education. The Quarterly Review of Distance Education, 6(2), 117-124. Retrieved from http://www. infoagepub.com/index.php?id=89\&i $=12$

Rovai, A. P. (2002). Building sense of community at a distance. International Review of Research in Open and Distance Learning, 5(1). 1-16. Retrieved from http://www. irrodl.Org/index.php/irrodl/article/view/79/153

Rovai, A. P. (2007). Facilitating online discussions effectively. Internet and Higher Education, 10, 77-88. doi:10.1016/j.iheduc.2006.10.001

Schrire, S. (2006). Knowledge building in asynchronous discussion groups: Going beyond quantitative analysis. Computers \& Education, 46, 49-70. doi:10.1016/j. compedu.2005.04.006

Shea, P., \& Bidjerano, T. (2009). Community of inquiry as a theoretical framework to foster "epistemic engagement" and "cognitive presence" in online education. Computers \& Education, 52(3), 543-553. doi:10/1016/j.compedu.2008.10.007 
Shea, P., Li, C. S., \& Pickett, A. (2006) Teacher presence student sense of learning community in fully online and web-enhanced college courses. The Internet and Higher Education, 9(3), 175-190. doi:10.1016/jheduc.2006.06.005

Tu, C. H., \& Mclsaac, M. (2002). The relationship of social presence and interaction in online classes. The American Journal of Distance Education, 16(3), 131-150. doi:10.1207/S15389286AJDE1603_2

Wallis, C. (2006, March 27). The multitasking generation. Time, 167(13), 48-55. Retrieved from http://www.time.com/time/archive/preview/0,10987,1174696,00.html

Wu, D., \& Hiltz, S. R., (2004). Predicting learning from asynchronous online discussions. Journal of Asynchronous Learning, 8(2), 139-52. Retrieved from http:// sloanconsortium.org/jaln/v8n2/predicting-learning-asynchronous-onlinediscussions 